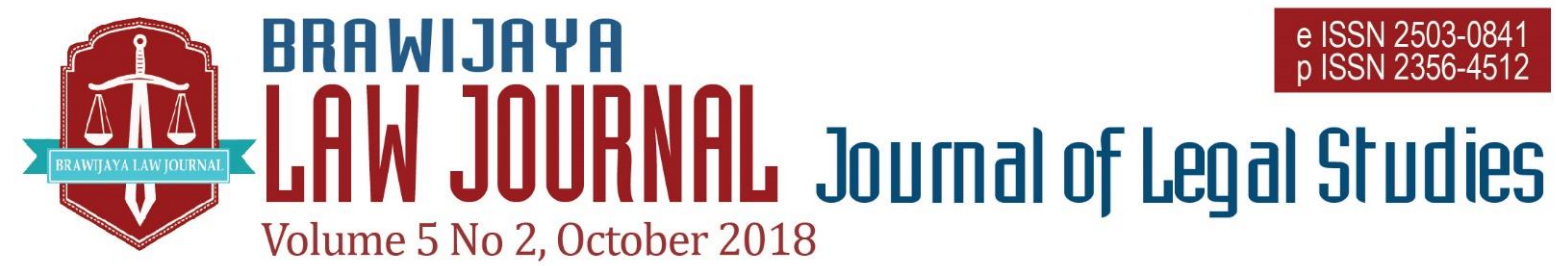

Nationally Accredited No. 32a/E/KPT/2017 Dated 26th April 2017

This work is licensed under a Creative Commons Attribution-NonCommercial 4.0 International License

\title{
Population Administration Policy: An Empirical and Juridical Examination
}

\author{
Donna Okthalia Setiabudhi ${ }^{1}$, Toar Neman Palilingan ${ }^{2}$, \\ Jeany Anita Kermite ${ }^{3}$ \\ ${ }^{1}$ Faculty of Law, Sam Ratulangi University \\ Email: donna_setiabudhi@yahoo.com \\ ${ }^{2}$ Faculty of Law, Sam Ratulangi University \\ Email: palilingann@gmail.com \\ ${ }^{3}$ Faculty of Law, Sam Ratulangi University \\ Email: jeankermite@yahoo.com
}

Submitted : 2018-09-14 | Accepted : 2018-10-26

\begin{abstract}
Manado is a city that has a large population, high population mobility and activities in all fields that are increasingly complex. However, actually it does not have a legal product that regulates population administration technically. This paper aims to analyse the population administration policies in the city of Manado and propose an ideal policy that can be pursued to establish an appropriate population administration service in this region. The research is a socio-juridical research. The method used is descriptive by giving a systematic, factual and accurate description of the issues of research.

The results indicated that population administration services in the city of Manado were still minimal and not optimal because there were no local regulations which accommodate all the typical conditions of communities. The lack of human resources both in quality and quantity in providing the population administration service to the community and the lack of attention the public to the importance of population administration for their lives, have made inappropriate populatuion administration service. Thus, it is argued that the existence of local regulations are needed to regulate population administration which can accommodate the conditions of the communities in Manado and can be a reference for the implementers in providing optimal services to the community.
\end{abstract}

Keywords: administrative law, public policy, population administration

\section{INTRODUCTION}

At this time, public services cannot be separated from human life because it is very needed and closely related to the life of peoples. In practice, several public service activities have certain characteristics and divided into several types of services and their implementation. It is argued that although there are existing laws in the privacy on personal data, however, those 
legal frameworks still developed in very sectoral nature. ${ }^{1}$ Hence, the government as a public service provider and needed by the community must be responsible and continue to strive to provide the best service for the improvement of public services.

One of several services by the local government is population administration services. This is a very important role in development, where in the population administration system can be known about population data and information that is appropriate to the situation of the population and about the condition of their residential area. ${ }^{2}$ The event of population requires valid evidence to be administered and recorded in accordance with the provisions of the legislation. Act No. 24 of 2013 concerning Population Administration affirms that the population administration in Indonesia will be performed through the application of the Population Administration Information System.

Basically, the population administration is closely related to the fulfillment of human rights because every person in the field of population has a right without discrimination. So it can be said that the implementation of an orderly population administration will support the realization of good governance, optimize democratization and protect human rights in order to improve the welfare of society. Achieving these conditions is not easy, because it requires complex prerequisites such as legal tools, institutional stability, apparatus capability, regularity of management, availability of financing up to public awareness support.

Rosadi, S.D, 'Protecting Privacy on Personal Data in Digital Economic Era: Legal Framework in Indonesia' (2018) 51 Brawijaya Law Journal, 143 $-157$
One of the strategic factors that must be organized and prepared to serve and effective is a legal basis and can guarantee protection and comfort for the population to obtain legal certainty domiciled in the territory of the Republic of Indonesia in accessing their rights as citizens and as Indonesian. Legislation required must not be discriminatory, clear (not multi-interpretative), not-contradictory (should be synergistic) with other laws and regulations in public services, so that it can be used as an instrument of population control, and can function to encourage the realization of a modern population administration services with good governance and clean government. A form of legal product needed is a local regulation.

Manado is a city that has a large population, high population mobility and activities in all fields that are increasingly complex but it does not yet have a legal product that regulates the population administration technically, therefore the author is interested in reviewing the population administration policies in the city of Manado and propose an ideal policy that can be pursued to establish an appropriate population administration service in this region.

\section{LEGAL MATERIALS AND METHODS}

The research is a socio-juridical research. The method used is descriptive method by giving a systematic, factual and accurate description of the research issue. It was conducted in the city of Manado by considering that Manado until now there is no local regulation on population administra-

Hendratno, E. T., \& Fitriati, R, 'The Study of Indonesia's Readiness To Cope With Demographic Bonus: A Review Of Population Law' (2015) 303 Journal of Indonesian Economy and Business, 195-219. 
tion. The data was analyzed through qualitative analysis. This analysis be based on the theoretical as a key of analysis in explaining the phenomenon of this research.

\section{RESULT AND DISCUSSION}

\section{Integrated Governance and Population} Administration Policy

Policy philosophy appears in a pluralistic society like Indonesia. The community consists of several interest groups and the government is considered as a unifier and has a strong control from all elements of the interest group into an integrated force. Therefore, to manage a pluralistic society, managerial ability is needed to manage conflicts that may arise due to differences in ethnic, religious, racial, and group backgrounds into useful something for society or nation. One of the tips for managing a pluralistic process certainly requires a policy in accordance with the wishes of the community and government. ${ }^{3}$

The policy is usually used in choosing and presenting the most important choices to be made, both in the life of government and private organizations. The policy is free from the connotations or nuances that are included in political words which are often believed to have a partial notion. ${ }^{4}$ A policy of decision that applies and characterized by consistent and repetitive behavior, both from those who make it and those who obey it (those affected by the policy). While public policy is a series of choices that are interconnected (including decisions that do not act) made by government agencies and officials.

\footnotetext{
Musanef, Sistem Pemerintahan Indonesia (Gunung Agung : Jakarta, 1985), 54 Ibid

5 E. Koswara, Otonomi Daerah, Untuk Demokrasi dan Kemandirian Rakyat (Yayasan Pariba: Jakarta, 2001) 92
}

Problems regarding policy are topics that are currently hotly discussed in both industrial and developing countries. Policy implementation is not just a mechanism for translating policy objectives into technical and routine procedures but also involves various other factors, namely resources, relations between organizational units, the level of bureaucracy to certain political groups who may not approve the policies that have been established. ${ }^{5}$

This view does not mention the most important factor of a policy that should be a reference to determine whether a policy is implemented or not. The intended factor is the people or society where the policy will be implemented. Grindle ${ }^{6}$ argues that attempts to explain this diver have led to the realization that implementation, even when successful, involves for more than a mechanical translation of goals into routine procedures, it involves fundamental question about conflict, decision making, and who gets what in a society.

Grindle also stated 2 (two) things that affecting the effectiveness of a policy, namely: ${ }^{7}$ The first, content of policy which contains interest affected, type of benefits, extend of change environed, site of decision making, program implementors, resourced committed; The second, context of implementation contains power, interest, regime characteristic, compliance and responsiveness.

In the implementation of decentralization, Rondinell and $\mathrm{Cheema}^{8}$ suggests the relationship of factors that influence the implementation of decentralization policy,

\footnotetext{
$6 \quad$ Ibid, 93

Ibid

Ibid 95
} 
namely 1) The compliance approach; an implementation is considered only a technical and routine problem so that the process of implementation does not contain political elements whose plans have been predetermined by the leaders political. 2) The political approach; that views administration as an integral part that is inseparable from the process of determining the policy in which the policy is changed, re-formulated even the large burden in the process of implementation.

In several notions of authority as mentioned above, the author concludes that authority has a different notion with competence. ${ }^{9}$ Authority is a formal power that comes from the law, while competence is a specification of authority, meaning whoever (legal subject) is given authority by law, then authorized to do something in the authority.

In the concept of population administration, the population has the meaning of people who live in the area or people who are legally entitled to live in the area. ${ }^{10}$ Administration includes activities that must be conducted by executive officers in an organization, serves to regulate, and completing collaborative efforts of a group of people who are deliberately gathered to achieve certain goals. The notion of administration in a narrow and broad sense, namely: ${ }^{11}$

a. In narrow meaning: comes from the word Administratie (Dutch), which includes note or registry, correspondence, minor bookkeeping, typing, agenda etc, which is clerical work. Thus,

9 I. Fachruddin, Pengawasan Peradilan Administrasi Terhadap Tindakan Pemerintah (Alumni, Bandung, 2014) 4

10 Bappenas, Pembangunan Kependudukan Keluarga Kecil Berkualitas serta Pemuda dan Olah Raga. (Jakarta2006) it is a small part of the activities of the administration.

b. In broad meaning: comes from the word Administration (English), is a series of activities or processes of cooperative activities for a group of people to achieve certain goals efficiently

The essence of population administration is the recognition of State to the public rights (domicile, relocation) and civil rights (12 important sectors) of the population in the field of population administration. The population adminis-tration is directed to fulfill the human rights of every person in the field of population administration without discrimination through professional public services. Population registration is done by recording population data, recording based on the reporting of population events and issuing population documents.

\section{The Examination of Empirical and Juridical to the Policy of Population Administration}

Population administration is a very important issue because it is in touch with all life activities in Indonesia. Almost all aspects of community life require population administration, even to register a mobile card needed a population administration. The issue of population, since independence of Indonesia has experienced problems because there is no administrative link between one and other interests even in ancient times a citizen could have a National Identity Card more than one place because there was no connection between one and another region.

11 S.A. Wahab, Analisis Kebijaksanaan: Dari Formulasi ke Implementasi Kebijaksanaan Negara. Jakarta : Bumi Aksara,2005), 32 
It has caused many difficulties in the administration of the State and government, for example in law enforcement.

Civil registration is the right of every citizen to obtaining an authentic deed from a state official. An example is a birth certificate. The child is born without a birth certificate will have difficulties when enters education. Likewise, in marriage, death and child status. Many benefits bring legal consequences for a person. A marriage certificate issued by a civil registry official, has a very big meaning in the future, when something happens. For example, to determining the heirs or can give directions to the court where he filed for divorce and others that are unwittingly important to the life of person.

The urgency of population administration be a reason the government to issues Act No. 24 of 2013 concerning Population Administration. Various facilities were provided by this law, the ease in the administering of population documents and the ease in civil registry based on Act No. 23 of 2013, among others:

a. The validity of electronic identity card that initially 5 (five) years changed become lifetime as along there is no change of data in the identity card. Thus, the population must not difficult extending the validity of their card.

b. The printing of document/electronic identity card. Since the implementation of electronic identity card recording in mass, the printing is carried out by the Ministry of Domestic Affairs that centered in Jakarta. Many people feel difficult to confirm if there is a mistake or occur delay. As a consequence, many peoples have inappropriate identity card. To prevent the difficulty in correcting the mistake of data in the identity card, it was planned in quarter III 2014 the printing of document will be delivered to the region. The local government through the Population and Civil Registry Offices at region level is given authority to print the electronic identity card.

c. The issuance of birth certificate whose reporting exceed 1-year period. Other easiness in administer the document in the Population and Civil Registry Office related to the issuance of birth certificate whose reporting exceed 1year period. Initially, the issuance requires the decision of State Court, it changed by the Decision of the Population and Civil Registry Office at region level. It is in line with the decision of Constitution Supreme dated 30 April 2013.

d. The issuance of Civil registry certificate. Before Act No.23 of 2006 is amended, the recording and issuance of the civil registry certificate is based on the principle where an event occur. With the new law the principle is amended, namely the principle in the place of domicile of the population. This is expected to encourage the public to take care of population and civil registration documents;

e. Article 44 of this law regulates the reporting of death. The point is that the reporting of death records which were originally the obligation of the population was changed to the obligation of the head of the environment or another name to report every death of his citizens to the implementing agency (the Population and Civil Registry Office). With this policy, it is expected that the death record will increase significantly. Because all this time public awareness to report and/or make death certificates is still relatively low; and 
f. The active of officers. The active system which was originally required by the population was changed to an active standard required by the government through officers. This means that the officer who serves the population administration affairs must be proactive to serve the population. That is why local governments must actively carry out population administration services.

Above all, various facilities in the law will be effective if further regulated by local regulations considering that local regulations are rules established in the framework of the implementation of local autonomy and with this local regulation it is hoped that population services can be carried out in line with the conditions of each local community but thus the city of Manado apparently did not yet have local regulations on population administration. The absence of this local regulation is clearly very influential in the implementation of population administration services because it is based on the law with the nature of regulation that is still abstract.

The problem of population administration in Indonesia is a very important role in development, where from the population administration system can be known about population data and information that is appropriate to the situation of the population and the condition of the area where the population lives. ${ }^{12}$ The Unitary State of the Republic of Indonesia based on Pancasila and the 1945 Constitution of the Republic of Indonesia is essentially obliged to provide protection and recognition of the determination of the personal status and legal status of each population and important event experienced by residents who are inside and or outside the territory the Unitary State of the Republic of Indonesia. Legal status is given to provide guarantees to residents to obtain justice. Justice is the goal of law enforcement efforts.

In addition, to the formation of local regulations, efforts to optimize population administration services in the city of Manado must be able to overcome the obstacles that occur. The government officials in the city of Manado in increasing orderly population administration must take some concrete steps. This is done to maximize the quality of services provided by the village official which is expected to be able to encourage the public to care more about the importance of orderly population administration.

As described above, efforts are expected to increase orderly population administration in the city of Manado. But some things often become obstacles to creating quality population administration services. Some obstacles such as:

a. The lack of community attendance in participating in any counseling carried out by village officials. The number of people attendance is influenced by the apathy of the community, the busyness of the daily routine of the communities, lack of socialization and minimal level of interaction.

b. A narrow service room so people have to wait outside the room and cause discomfort.

c. The minimum quantity of employees in serving the community causes queues and processes that tend to be slow.

d. The community has not fully understood the completeness of the document file 
which is a condition in the service process for population administration.

To overcome these obstacles, the government of Manado needs to do several things, including:

a. Always intense to conduct socialization and counseling. For this reason, the village office distributes invitation to the head of the neighborhood and community leaders so that the peoples were enthusiastic about attending the counseling in the village.

b. Renovating the service room so that it is wider and more comfortable. The service room is also equipped with air conditioning and a front desk.

c. Increase the number of employees in charge of serving the community to avoid long queues.

d. Besides the socialization and counseling held by the village office, the head and community leaders also took part in informing or giving understanding about the completeness of the document file.

It presents that in the population administration service in the city of Manado, there is no optimal service system because there is no substance in the local law that governs, the implementation of the duties of local government officials in population problems is not yet clear and community support is not optimal so needs issues the local regulations immediately that fulfill the requirements by taking into account the principles of the establishment of good local regulations in order to support optimization in implementation.

\section{CONCLUSION AND SUGGESTION}

In Manado, the population administration services are still not optimal because there are no local regulations issued or established to accommodate all the unique conditions of communities. The lack of human resources both in quality and quantity in providing the population administration service to the community and the lack of attention the public to the importance of population administration for their lives, have made inappropriate populatuion administration service. Thus, it is recommended to have local regulations to regulate population administration which can accommodate the conditions of the communities in Manado and can be a reference for the implementers in providing optimal services to the community.

\section{REFERENCES}

\section{Books}

Bappenas, Pembangunan Kependudukan Keluarga Kecil Berkualitas serta Pemuda dan Olah Raga (Jakarta: Bappenas, 2006)

Fachruddin, I, Pengawasan Peradilan Administrasi Terhadap Tindakan Pemerintah (Alumni, Bandung, 2004)

Koswara, E., Otonomi Daerah, Untuk Demokrasi dan Kemandirian Rakyat (Yayasan Pariba: Jakarta, 2001)

Musanef, Sistem Pemerintahan Indonesia (Gunung Agung : Jakarta, 1985)

Wahab, S.A., Analisis Kebijaksanaan: Dari Formulasi ke Implementasi Kebijaksanaan Negara. (Bumi Aksara: Jakarta, 2005)

\section{Journal Articles}

Hendratno, E. T., \& Fitriati, R 'The Study of Indonesia's Readiness To Cope With Demographic Bonus: A Review Of Population Law' (2015) 303 Journal of Indonesian Economy and Business

Mason, A. 'Population change and economic development: What have we learned 
from the East Asia experience?' (2003)

11 Applied Population and Policy

Rosadi, S.D. ' Protecting Privacy on Personal

Data in Digital Economic Era: Legal

Framework in Indonesia' (2018) 51

Brawijaya Law Journal 